For a Pragmatics of the Useless 


\section{For a}

Pragmatics

of the

Useless 
ERIN MANNING 
(C) 2020 DUKE UNIVERSITY PRESS

All rights reserved

Printed in the United States of America on acid-free paper $\infty$

Designed by Courtney Leigh Richardson

Typeset in Courier and Whitman by Westchester Publishing Services

Library of Congress Cataloging-in-Publication Data

Names: Manning, Erin, [date] author.

Title: For a pragmatics of the useless / Erin Manning.

Other titles: Thought in the act.

Description: Durham : Duke University Press, 2020. | Series: Thought in the act | Includes bibliographical references and index.

Identifiers: LCCN 2020014223 (print) | LCCN 2020014224 (ebook)

ISBN 9781478010029 (hardcover)

IS BN 9781478011071 (paperback)

IS BN 9781478012597 (ebook)

Subjects: LCSH: Racism-Psychological aspects. | Psychoanalysis and racism. |

Racism.

Classification: LCC BF175.4.R34 M366 2020 (print) | LCC BF175.4.R34

(ebook) | DDC 155.8/2-dc23

LC record available at https://lccn.loc.gov/2020014223

LC ebook record available at https://lccn.loc.gov/2020014224

Cover art: Ploppiñata, spaZe. (c) Erin Manning.

Photograph by Leslie Plumb. Courtesy of the artist. 
With SenseLab 